\section{Twenty-five-year-old woman with palpitations and hypertrophic cardiomyopathy}

\section{CLINICAL INTRODUCTION}

A 25 -year-old woman with a diagnosis of hypertrophic cardiomyopathy (HCM) and pre-excitation on ECG presented with unexplained syncope and daily palpitation. Genetic testing was positive for lysosome-associated membrane protein 2 (LAMP2) mutation which confirmed the diagnosis of Danon disease. Her younger sister was diagnosed with a similar condition and received a defibrillator implantation. Her 12-lead ECG (figure 1) and a long strip tracing (figure 2) are shown below.

\section{QUESTION}

Where is the location of the accessory pathway and what is the next appropriate management?

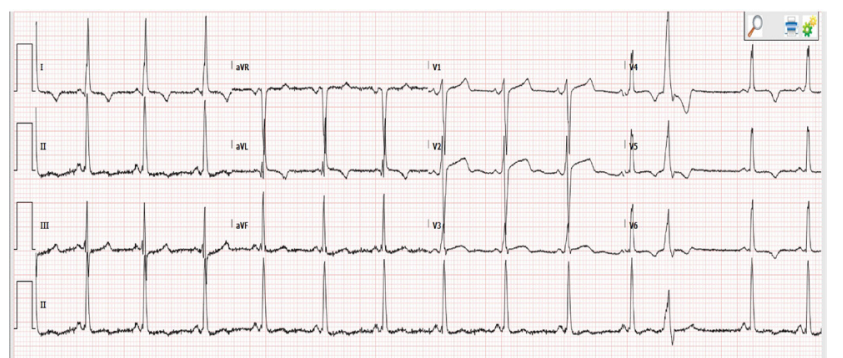

Figure 1 12-lead ECG.

A. Anteroseptal pathway and catheter ablation

B. Mid-septal pathway and pacemaker/defibrillator implantation

C. Right lateral pathway and catheter ablation

D. Fasciculoventricular pathway and electrophysiological study

E. Left lateral pathway and electrophysiological study 


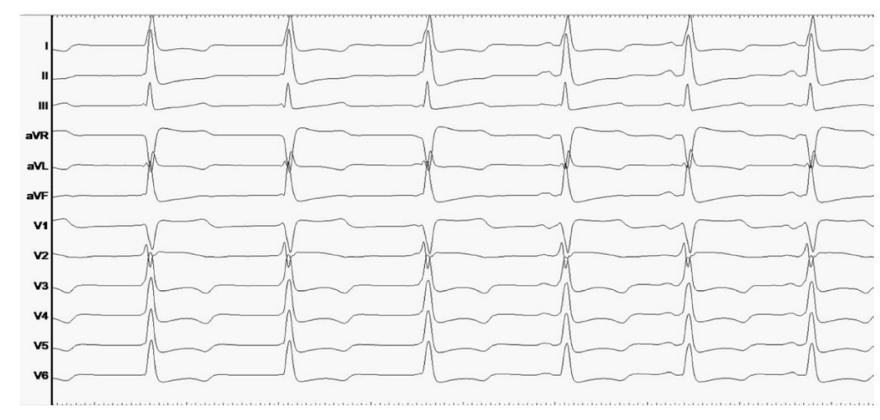

Figure 2 A long strip of the ECG tracing.

\section{ANSWER: D}

The correct answer is fasciculoventricular (FV) pathway and electrophysiological study should be the next step of management. Figure 1 demonstrates a 12-lead ECG showing sinus rhythm with a slightly short PR interval of $112 \mathrm{~ms}$ and evidence of pre-excitation, especially in precordial leads. The right lateral pathway would have a negative delta wave in lead V1 and left lateral pathway would have it in lead I and aVL. Figure 2 demonstrates a junctional rhythm on the first three beats and sinus rhythm on the last three beats of tracing. There is pre-excitation present as seen by slurring in upstroke of leads V2, V3, V4, and limb leads. Of note, the degree of pre-excitation is same in the sinus and junctional beats. In a typical atrioventricular accessory pathway, junctional beats will not show any pre-excitation since the depolarisation starts below the atrium and does not engage the accessory pathway. Hence, the finding of the similar degree of pre-excitation for junctional and sinus beat is diagnostic for FV pathway. Her electrophysiological study confirmed this diagnosis with a fixed HV interval. In addition, she had easily inducible atrioventricular nodal re-entry tachycardia which most likely caused her palpitation. Successful ablation of the slow pathway was performed. A single chamber defibrillator was implanted for prevention of sudden cardiac death from HCM. FV pathway had never been demonstrated to be the key component of re-entrant tachycardia due to its short distance and considered to be benign. ${ }^{1}$ Its pre-excitation pattern could mimic anteroseptal or mid-septal pathway and lead to the unnecessary risk of complete heart block with an attempted catheter ablation. Danon disease is an X linked dominant lysosomal storage disease derived from the genetic defects in LAMP gene mutation with multiorgan involvement. $^{2} 3$ Pre-excitation is very common and risk for sudden cardiac death is high ${ }^{34}$ in patients with Danon disease.

\section{Krittapoom Akrawinthawong, ${ }^{\circ}$ Vineet Kumar}

Cardiovascular Medicine, University of Alabama at Birmingham, Birmingham, Alabama, USA

Correspondence to Dr Krittapoom Akrawinthawong, Cardiovascular Medicine, University of Alabama at Birmingham, Birmingham, AL 35233, USA; krittapoom.a@ gmail.com

Contributors KA and VK wrote and revised the manuscript.

Funding The authors have not declared a specific grant for this research from any funding agency in the public, commercial or not-for-profit sectors.

Competing interests None declared.

Patient consent for publication Not required.

Provenance and peer review Not commissioned; externally peer reviewed.

\section{(1) OPEN ACCESS}

Open access This is an open access article distributed in accordance with the Creative Commons Attribution Non Commercial (CC BY-NC 4.0) license, which permits others to distribute, remix, adapt, build upon this work non-commercially, and license their derivative works on different terms, provided the original work is properly cited, appropriate credit is given, any changes made indicated, and the use is non-commercial. See: http://creativecommons.org/licenses/by-nc/4.0/.

(C) Author(s) (or their employer(s)) 2019. Re-use permitted under CC BY-NC. No commercial re-use. See rights and permissions. Published by BMJ.

\section{Check for updates}

To cite Akrawinthawong K, Kumar V. Heart Asia 2019;11:e011174.

Heart Asia 2019;11:e011174. doi:10.1136/heartasia-2018-011174

\section{REFERENCES}

1. Rohrhoff NJ, Finne HA, Rodriguez Y. A sailor's dilemma: a case of preexcitation via a fasciculoventricular pathway. HeartRhythm Case Rep 2017;3:364-7.

2. D'souza RS, Mestroni L, Taylor MRG. Danon disease for the cardiologist: case report and review of the literature. J Community Hosp Intern Med Perspect 2017;7:107-14.

3. D'souza RS, Levandowski C, Slavov D, et al. Danon disease: clinical features, evaluation, and management. Circ Heart Fail 2014;7:843-9.

4. Sternick EB, Oliva A, Gerken LM, et al. Clinical, electrocardiographic, and electrophysiologic characteristics of patients with a fasciculoventricular pathway: the role of PRKAG2 mutation. Heart Rhythm 2011;8:58-64. 